Article

\title{
Does off-Farm Migration of Female Laborers Inhibit Land Transfer? Evidence from Sichuan Province, China
}

\author{
Kai Huang ${ }^{1,+}$, Xin Deng ${ }^{2,+} \mathbb{C}$, Yi Liu $^{1}$, Zhuolin Yong ${ }^{1}$ and Dingde $\mathrm{Xu}^{1,3, * \mathbb{C}}$ \\ 1 College of Management, Sichuan Agricultural University, Chengdu 611130, China; \\ hk666@stu.sicau.edu.cn (K.H.); lyx1@stu.sicau.edu.cn (Y.L.); zhuolinyong@stu.sicau.edu.cn (Z.Y.) \\ 2 College of Economics, Sichuan Agricultural University, Chengdu 611130, China; dengxin@sicau.edu.cn \\ 3 Sichuan Center for Rural Development Research, College of Management of Sichuan Agricultural University, \\ Chengdu 611130, China \\ * Correspondence: dingdexu@sicau.edu.cn \\ + These authors contributed equally to this work and should be considered co-first authors.
}

Received: 19 November 2019; Accepted: 7 January 2020; Published: 9 January 2020

\begin{abstract}
With the feminization of agriculture, the role of women in the rural land transfer market is becoming increasingly important. However, at present, there is little research focusing on the relationship between the off-farm migration of female laborers and land transfer rates. Using data on 1652 agricultural land plots owned by 232 rural households in Sichuan Province in 2014, IV-Probit (The Probit model of tool variable method is added) and IV-Tobit (The Tobit model of tool variable method is added) models were constructed to explore the relationships between off-farm migration and rural household land transfer (whether the rural households have land transfer-in and the area of land transfer-in by rural households) with consideration of gender. The results show that: (1) Off-farm labor migration has a negative and significant impact on rural households' land transfer-in rates. Under the same conditions, the off-farm migration rate increased by $10 \%$, the probability of transfer-in land decreased by $2.6 \%$ on average, and the transfer-in area decreased by $2.7 \mathrm{mu}$ on average. (2) The off-farm migration of female laborers inhibited land transfer-in rates. For every $10 \%$ increase in female labor migration, the probability of land transfer-in decreased by an average of $2.1 \%$, and the land transfer-in area was reduced by an average of $3 \mathrm{mu}\left(1 \mathrm{mu}=667 \mathrm{~m}^{2}\right.$ or $\left.0.067 \mathrm{ha}\right)$. However, the impact of male labor migration on farmers' land transfer-in is negative and not significant. This study provides a novel, gendered perspective to understand land transfer-in behaviors in hilly areas, which can provide further information on off-farm labor migration and the rational allocation of land resources.
\end{abstract}

Keywords: land transfer; gender perspective; off-farm labor migration; Sichuan Province; China

\section{Introduction}

Land and labor are the core elements of agricultural production. Farm output quotas are fixed on a household basis in the current system of rural land in China, implemented since the 1980s. It has greatly stimulated the productivity of rural households and rapidly developed the rural economy of China [1-7]. However, due to the restriction of the land quality equalization policy applied when land is contracted for production and assigned to households, cultivated land in the vast, hilly areas of China tends to be "small, scattered, and weak" [8]. With the development of the social economy, the small, scattered, and weak land-use problem has become increasingly prominent and has gradually become a major restriction to China's rural economic development and food security [9-16]. With the continuous industrialization and urbanization of China, the household contract responsibility system, which 
features decentralized management, is increasingly unable to meet the needs of modern agricultural development, which is characterized by "marketization, scale, and informatization" [17]. It is generally believed in academic circles that the moderate scale of land management plays an important role in limiting land fragmentation. In such management, land transfer is an important method of realizing a moderate scale of land management [18-22].

Land transfer has effects on the moderate scale management of land, raising rural household income, and preventing land abandonment [23]. Since the mid-1980s, Chinese governments at all levels have successively introduced a series of policies to encourage land transfer and promote the integration of rural land resources [24,25]. Although China has successively issued a series of policies to allow the transfer of "land-use rights" with compensation, the land transfer rate in China has not been high until now. For example, China's land transfer rate was only $2.53 \%$ in 1999 . Since the beginning of this century, with the implementation of a series of land policies (such as the "separation of three rights"), the size and form of land transfers in China have changed dramatically. The land transfer rate increased from $12 \%$ in 2010 to $37 \%$ in 2017, an average annual growth of $17.5 \%$ [26]. After 30 years of development of China's land transfer market, although the transfer rate has increased significantly, it is still relatively low compared with those of other developed countries in Europe and North America, and is even lower than that in China in the last century. For example, the land transfer rate in the United States was 43\% in 1992. In 1999, the land transfer rate in Uganda was 36\% and, in the Philippines, it was $51 \%[27,28]$. Sichuan is a large, mountainous province in China and a major agricultural province, and its land transfer rate has been lower than the national average. In Sichuan Province in 2016, an area of 19.703 million mu of rural land was transferred ( $1 \mathrm{mu}=667 \mathrm{~m}^{2}$ or $\left.0.067 \mathrm{ha}\right)$, accounting for $33.85 \%$ of the household contract management size, and less than the national average of $1.25 \%$. The division of labor in rural households, especially off-farm labor migration, is one of the important causes of this low land transfer rate [29-31].

Since China's reform and opening up, with the gradual elimination of policy barriers and the transformation of the economic structure, many rural laborers have migrated to cities to seek urban off-farm sector employment [32-34]. Since 1984, when China opened the door for rural residents to work in cities, the rural labor force has decreased while urbanization and industrialization have increased [35-40]. In 1978, the number of rural off-farm workers was 32 million. Off-farm payrolls have grown faster since the mid-1980s, reaching 103 million in 1992 and 288 million by the end of 2018. In the 40 years from 1978 to 2018, the number of rural off-farm jobs increased by 257 million in absolute terms, an eight-fold increase [41]. This massive migration of the labor force has resulted in a fundamental structural transformation of the relationship between rural people and land. This not only alleviates the contradiction of "more people and less land" in China, but has also led to demands from political and academic circles for the reallocation of land resources [42].

Off-farm labor migration has always been considered an important driver of rural households' land use (including land transfers) [43,44]. However, inconsistent relationships between off-farm labor migrants and land transfer have been reported in the literature. According to the findings from previous studies, the correlation between the two mainly includes the following three aspects: (1) Off-farm employment of the labor force promotes the transfer of rural households' land. For instance, Deng et al. [45] reported an inverted U-shaped relationship between off-farm employment, land transfer behavior and land transfer size, with inflection points of $55.55 \%$ and $56.22 \%$, respectively. Xu et al. [46] reported that off-farm employment encourages rural households to transfer out their land, while part-time employment has an inverted U-shaped relationship with land transfer. Yao et al. [47] reported that off-farm employment can promote the development of the farmland transfer market by increasing the farmland inflow of heterogeneous rural households. The higher is the off-farm employment rate of the rural labor force, the higher is the incidence of land transfer. (2) There is no causal relationship between off-farm employment and land transfer and, to some extent, it will inhibit the development of the land transfer market. For example, Chen et al. [48] reported that there is no causal relationship between the proportion of off-farm labor migration and the proportion of land transfer, and the two 
do not develop in unison. Qian [49] reported that, due to the increasing rate of rural part-time and agricultural feminization, and the increasing proportion of agricultural machinery inputs, off-farm employment does not accelerate the rate of land transfer. Ma et al. [50] reported that, due to the unique social security function of rural land, off-farm labor migrants often do not give up their land-use rights. (3) They both promote and restrict each other. For example, Li et al. [51] argued that, on the one hand, the migration of surplus rural laborers accelerates the speed of land transfer; on the other hand, due to the urban-rural dual structure, especially the household registration system, insufficient off-farm labor migrants inhibit the efficiency of land transfer.

These above studies have laid a solid foundation with which to understand the correlation between off-farm labor migration and land transfer. However, few studies have focused on the impact of female labor migration on land transfer, especially the impact of female labor migration on land transfer-in, based on gender perspectives with land plots as the research scale. The present study analyzed the impact of female labor migration on land transfer from the perspective of behavioral decision-making of land transfer-in. The reasons for this arrangement are: (1) Under the current household contract responsibility system, the behavior decision of land transfer-in determines the realization of the moderate scale of land management. (2) Among the many factors that still affect the land transfer level in China, the inhibiting effect of female labor migration on land transfer-in may be important. Since women are expected to earn far less than men in off-farm employment and are easily burdened by housework, as well as the common divisions of labor that males engage in the off-farm sector and females in the farm sector and the traditional concept of "breadwinning men and homemaking women" in Chinese rural households [52-55], there is hysteresis in female off-farm labor migration and the feminization of agricultural production (the off-farm migration of the female labor force is lower than that of the male labor force). In 2001, $82.1 \%$ of rural women were engaged in pure agriculture, while on $64.7 \%$ of men. In $2017,65.2 \%$ of migrant workers were male, and $34.8 \%$ female [56].

\section{Theoretical Analyses}

The New Economics of Labor Migration (NELM) was proposed by Stark in the 1980s. Its core idea is that rural households will rationally allocate their labor and land resources on the premise of maximizing family benefits and minimizing risks [57]. Based on this, the present study defined a theoretical model of rural households' agricultural income maximization as:

$$
\begin{gathered}
Y=Y 1-Y 2 \\
Y 1=X A+T S \\
Y 2=(X+\Delta X) A+(T+\Delta T) S-(C+R)
\end{gathered}
$$

In the above equations, $Y$ is agricultural income maximization, $Y 1$ is the family income before the transfer-in of rural households' land, $Y 2$ is the family income after the transfer-in of rural households' land, $X$ represents the amount of land contracted by rural households before land transfer-in, $A$ represents the output per unit of land, and XA represents the household's agricultural income. $T$ is household off-farm employment time, $S$ is the household off-farm employment wage rate, and TS is household off-farm income. $\Delta X$ represents the amount of land change after land transfer-in, $\Delta T$ is the change in off-farm employment time after land transfer, $C$ is the cost of a land transfer transaction, and $R$ is land transfer. The term $(X+\Delta X) A$ is household farming income after land transfer-in and $(T+\Delta T) S$ is the household off-farm income after the land transfer-in. If $Y<0$, the rural households choose to transfer-in the land; if $Y \geq 0$, the rural households choose not to transfer-in the land.

At the 19th national congress of the communist party of China (CPC) in 2017, the "rural revitalization strategy" was established, which proposed to keep the land contract relationship stable 
and permanent, and extend it for another 30 years after the second round of land contracts expires [58]. China's household contract responsibility system will remain unchanged in the long run. Due to the hysteresis of rural female labor migration, the proportion of women in agricultural production is gradually increasing and the female rural labor force has become the main component of rural market economic activities [59]. In 2016, 47.5\% of China's female labor force was engaged in agricultural production, and $52.5 \%$ were engaged in non-agricultural production. Theoretically, in a relatively closed environment, the development of technology is relatively slow in the short term and changes in capital input are relatively small. In this case, a certain amount of labor force corresponds to a certain size of land management. When the family labor force migrates for off-farm employment, the area of land that the family can manage decreases, which encourages them to transfer-out land that cannot be cultivated. In contrast, a relative surplus of labor will encourage households to transfer-in the land and expand the scale of production.

Therefore, the off-farm migration of female rural laborer may affect land transfer-in rates in the following ways: (1) When female rural laborers migrate off-farm, the family labor force is insufficient and the willingness of rural households to transfer-in land is low. Moreover, as female laborers are the "fresh troops" of agricultural production in the context of agricultural feminization, their off-farm migration will inhibit land transfer-in more than that of men. (2) When female laborers choose to stay behind, it is usually because the expected income of agricultural production and the opportunity cost of off-farm employment are relatively high, and the remaining female labor force increases the family labor force, increasing the ability of rural households to engage in agricultural production. Then, there is an incentive to expand the scale of operation and increase agricultural income, thus they are more willing to transfer-in land.

Based on the above theoretical analysis, the present study tested the following research hypotheses:

Hypothesis 1 (H1). There is a negative impact of off-farm labor migration on land transfer-in (and the area transfer-in).

Hypothesis 2 (H2). Female labor migration has more negative effect on land transfer-in (and the area transfer-in) than male migration.

\section{Data and Methods}

\subsection{Study Areas}

Sichuan province, an important exporter of labor to the rest of China and a typical agricultural province, is located in the southwest of China [60]. It covers $486,052 \mathrm{~km}^{2}$ and had a population of 91.13 million in 2017, of which the rural population was 59.97 million, accounting for $65.58 \%$. Its GDP was 36,980 billion yuan, and its total agricultural output was 40.42 billion yuan. Since the mountainous and hilly terrain area of Sichuan province accounts for about $90 \%$ of the total area, the land is not conducive to large-scale agricultural operations [61,62].

\subsection{Data Sources}

The data used in this research mainly came from a household survey conducted in Guang yuan, Zigong, and Shehong districts (counties) of Sichuan Province, China, in April 2014. This survey used questionnaire-based face-to-face interviews of households, involving questions on family structure (labor force, numbers of elderly members and children, and off-farm payrolls), income (agricultural and non-agricultural income, household agricultural assets, total household assets, etc.), and land use (land transfer, land acquisition, land abandonment, and self-cultivated land). In terms of specific sampling methods, this study adopted with equal probability of selection within the stratum to generate samples. First, based on the studies by Cao et al. (2018), Luo et al. (2007), and Rozella et al. (1996) [63-65], with the per capita gross value of industrial output, 183 districts (counties) in Sichuan Province were divided 
into three groups. Then, one district (county) was randomly selected from each group to obtain three sample districts (counties). Second, by the same method, all the villages and towns in each sample area (county) were randomly divided into two groups. Third, two villages were randomly selected from each sample township according to their level and location of social and economic development. Finally, 20 rural households were selected randomly from each village by using the village roster and a random number table. Through the above process, questionnaires were obtained from 240 households. After logical screening, valid samples were obtained from 232 households, involving 1652 land plots. The effective recovery rate of questionnaires was up to $97 \%$.

\subsection{Methods}

\subsubsection{Dependent Variable}

The dependent variable this study focused on was the transfer-in of rural households' land, which was mainly measured from two aspects: (1) whether rural households have land transfer-in; and (2) the area of land that rural households transfer-in.

\subsubsection{Independent Variable}

Off-farm labor migration with consideration of gender was the independent variable studied in the present study. This study did not strictly distinguish between part-time and off-farm employment, but uniformly classified it as off-farm labor migration. This study mainly measured this by the following two aspects: (1) the impact of off-farm migration on land transfer-in; and (2) the impact of off-farm migration on land transfer-in area. Among them, when investigating the impact of off-farm labor migration on land transfer-in, the core independent variable was the household off-farm labor migration rate, which was measured by the proportion of the total number of off-farm employees and part-time employees in the total labor force. When discussing the influence on land transfer-in from the perspective of gender, the labor migration rate of each gender was used as the focus variable, which was specifically measured by the proportion of male and female off-farm employment and prat-time employment in total household labor force.

To reduce the impact of missing variables on the research results, Deng et al. Mullan et al. and Xu et al. $[47,48,66]$ were referred. In this study, the characteristics of the head of a household (such as age and educational level of the head of the household), family characteristics (including area of cultivated land per people, numbers of the elderly and children, whether there are farmers whose age is over 64 years old, the non-current assets of a family, agricultural non-current assets, etc.), and land plots features (such as the presence of irrigation, distance from home, massif terrain attributes, etc.) were included, as the control variables in the model $[66,67]$.

\subsubsection{Method Selection}

Probit and Tobit models were adopted to explore the impact of off-farm labor migration on whether rural households have land transfer-in and the area of land transfer-in, in consideration of gender.

$$
\begin{aligned}
& R_{i}=\beta_{0}+\beta_{1} \text { Migration }_{i}+\beta_{i} X^{\prime}+\varepsilon_{i} \\
& A_{i}=\beta_{0}+\beta_{1} \text { Migration }_{i}+\beta_{i} X^{\prime}+\varepsilon_{i}
\end{aligned}
$$

where $R_{i}$ and $A_{i}$ represent the land transfer-in behavior of household $i$ (whether land is transfer-in and the area of land transfer-in, respectively). Migration $_{i}$ is the core independent variable of this research model (the proportion of rural labor off-farm migration, the proportion of male labor off-farm migration, and the proportion of female labor off-farm migration). The vector $X^{\prime}$ represents the control variable, $\beta_{0}$ is a constant term, $\varepsilon_{i}$ is a disturbance term, and $\beta_{1}$ and $\beta_{i}$ are the coefficients to be estimated for the related variables. 
In addition, due to the possible causal relationship between off-farm labor migration and land transfer-in, the core independent variables in this study may be endogenous. To solve the endogeneity problem in off-farm labor migration, this study set the mean ratio of off-farm labor migration to the total labor force in the same village except the survey households as the instrumental variable. That is: $I V$ Migration $=\left(\right.$ Migration $_{1}+$ Migration $_{2}+\ldots+$ Migration $\left._{n-1}\right) /(n-1)$ Then, IV-Probit and IV-Tobit models were used to explore the impact of off-farm labor migration on land transfer-in incidence and area, respectively, to ensure robust results. The model formula was as follows:

$$
\begin{aligned}
& R_{i}=\alpha_{0}+\alpha_{1} I V \text { Migration }_{i}+\alpha_{i} X^{\prime}+\theta_{i} \\
& A_{i}=\alpha_{0}+\alpha_{1} I V \text { Migration }_{i}+\alpha_{i} X^{\prime}+\theta_{i}
\end{aligned}
$$

where the definitions of the variables are similar to those in Equations (4) and (5). The modeling process was conducted using the Stata 13.0 software program (StataCorp. LLC, College Station, TX, USA).

\section{Results}

\subsection{Descriptive Statistical Analysis}

Table 1 shows the descriptive statistics of the variables involved in the models. The land transfer-in probability and scale were relatively small. Among the 232 sampled rural households, only $2 \%$ transfer-in the land. The mean area of the 1652 plots of transfer-in land was $0.01 \mathrm{mu}$. The per capita cultivated size of the land was $0.86 \mathrm{mu}$ and the average distance from the plot to home was $0.61 \mathrm{~km}$. The household heads were mainly middle-aged and elderly, with low levels of education. The average age of the household head was 58.19 years and the average length of education was 5.91 years. The off-farm labor migration rate was $54.52 \%$, of which men comprised $33.25 \%$ and women $21.27 \%$.

\begin{tabular}{|c|c|c|c|}
\hline Variables & Definition and Coding & Mean & SD \\
\hline Transfer-in & Whether the rural households have land transfer-in $(1=$ Yes; $0=$ No $)$ & 0.02 & 0.14 \\
\hline Area -in & The area of land transfer-in by rural households $\left(\mathrm{mu}^{\mathrm{a}}\right)$ & 0.01 & 0.12 \\
\hline Migration & Labor migration/total household labor force (\%) & 54.52 & 28.71 \\
\hline Female-migration & Female labor migration/total household labor force (\%) & 21.27 & 18.99 \\
\hline Male-migration & Male labor migration/total household labor force (\%) & 33.25 & 20.44 \\
\hline Head age & Age of household head (year) & 58.19 & 10.37 \\
\hline Head edu & Education level of household head (year) & 5.94 & 3.4 \\
\hline Per size & Per capita cultivated size $\left(\mathrm{mu}^{\mathrm{a}}\right)$ & 0.86 & 0.68 \\
\hline Elder Child & Numbers of elderly men and children in the family & 1.47 & 1.14 \\
\hline Elder agri & Whether there are elderly farmers $>64$ years old $(1=$ Yes; $0=$ No $)$ & 0.27 & 0.44 \\
\hline Fixed asset & Household fixed assets $\left(10,000\right.$ yuan $\left.^{b}\right)$ & 16.14 & 20.36 \\
\hline Agri asset & Household agricultural fixed assets $\left(10,000\right.$ yuan $\left.{ }^{b}\right)$ & 0.38 & 0.68 \\
\hline Irrigation & Whether the plot can be irrigated $(1=$ Yes; $0=\mathrm{No})$ & 0.46 & 0.5 \\
\hline Right & $\begin{array}{l}\text { Whether the households' land has been confirmed the right to } \\
\qquad \text { contract }(1=\text { Yes; } 0=\text { No })\end{array}$ & 0.87 & 0.34 \\
\hline Distance & Distance from the plot to the home $(\mathrm{m})$ & 610.52 & 829.57 \\
\hline Location 1 & Whether the plot is located on a plain $(1=$ Yes; $0=\mathrm{No})$ & 0.12 & 0.32 \\
\hline Location 2 & Whether the plot is located on a mountain $(1=$ Yes; $0=$ No $)$ & 0.82 & 0.39 \\
\hline Location 3 & Whether the plot is located on a hill $(1=$ Yes; $0=\mathrm{No})$ & 0.06 & 0.25 \\
\hline
\end{tabular}

Table 1. The definition and data description of the variables in the model.

Note: ${ }^{\mathrm{a}} 1 \mathrm{mu}=667 \mathrm{~m}^{2}$ or 0.067 ha; $^{\mathrm{b}} 1$ US dollar $=6.119$ Yuan in 2014.

\subsection{Econometric Model Results}

\subsubsection{The Impact of Off-Farm Labor Migration on Land Transfer-in}

Table 2 shows the impact of off-farm labor migration on land transfer-in. Among them, Models 1-5 show the results of the Probit regression model of rural household transfer-in incidence. Among them, 
Models 1 and 2 are the baseline regressions using the Probit model; Model 1 is the Probit regression including only core variables, while Model 2 includes control variables based on Model 1. Models 3-5 used IV-Probit, and Model 5 is the marginal effect result obtained by the model. Similarly, Models 6-10 are regressions of the land transfer-in area model; Models 6 and 7 are Tobit baseline regressions, while Models 8-10 are the IV-Tobit models that included the instrumental variable.

All models were significant at a level of $p<0.05$, indicating that at least one independent variable in the model was significantly correlated with the dependent variable (Table 2$)$. At the same time, the endogeneity test statistics of Models 3-6 and 8-10 were significant $(p<0.05)$, indicating that the core independent variable of the model was endogenous and the method of its use was correct.

In terms of the impact of off-farm labor migration on rural households' land transfer-in decisions, Migration negatively affected rural households' land transfer-in $(p<0.01)$ and the results were robust. All other things being equal, every $10 \%$ increase in Migration reduced the land transfer-in incidence by $2.6 \%$ on average. Migration was significantly and negatively correlated with the land transfer-in area $(p<0.05)$. With other conditions held constant, every $10 \%$ increase in Migration reduced the average transfer-in area by $2.7 \mathrm{mu}$.

Looking at the impact of the other control variables on transfer-in of rural household land, the impact of Head age on Transfer-in was not significant. Head edu was negatively impacted on Transfer-in $(p<0.10)$. Per size, Right, and Distance were significantly negatively impacted on Transfer-in and Area-in. Agri assets and Irrigated variables were positively impacted on Transfer-in and Area-in.

\subsubsection{The Impact of Off-Farm Labor Migration on Land Transfer-in from the Perspective of Gender}

Table 3 shows the impact of Off-farm labor migration on land transfer-in from the perspective of gender. Similar to Models 1-10, Models 11-15 show the results of the Probit regression model of whether rural households transfer-in the land. Models 11 and 12 are the benchmark regressions using the Probit model. Model 11 is the Probit regression model including only the core variables, while Model 12 includes the control variables as well. Models 16-20 show the results of the regressions of the area of transfer-in land; Models 16 and 17 are Tobit benchmark models, while Models 18-20 are IV-Tobit models that include the instrumental variable.

All models were significant at $p<0.01$, indicating that at least one independent variable in each model was significantly correlated with the dependent variable (Table 3 ). The endogeneity test statistics of Models 13-16 and 18-20 were also significant at $p<0.01$, indicating that the core independent variable of each model was endogenous and the method of using the instrumental variables was correct.

In terms of the impact of off-farm labor migration on rural household land transfer-in incidence and area, Female migration negatively affected Transfer-in and Area-in $(p<0.01)$ and the results were robust. With other conditions held constant, every $10 \%$ increase in Female migration reduced Transfer-in by $2.1 \%$ on average and Area-in by $3 \mathrm{mu}$ on average. Male migration was not correlated with Transfer-in.

In terms of the impact of other control variables on land transfer-in, the impact of household head characteristics on land transfer-in were not significant. Per size, Fixed asset, Right, Distance and Fixed asset were significantly negatively impacted on Transfer-in and Area-in. Elder Child, Agri assets and Irrigated variables were positively impacted on Transfer-in and Area-in. 
Table 2. Results of the econometric model of the impact of off-farm labor migration on land transfer-in.

\begin{tabular}{|c|c|c|c|c|c|c|c|c|c|c|}
\hline \multirow[b]{2}{*}{ Variables } & \multicolumn{5}{|c|}{ Whether the Households Have Land Transfer-in } & \multicolumn{5}{|c|}{ The Area of Households' Land Transfer-in } \\
\hline & Model 1 & Model 2 & Model 3 & Model 4 & Model 5 & Model 6 & Model 7 & Model 8 & Model 9 & Model 10 \\
\hline Migration & $\begin{array}{c}-0.0069^{* * *} \\
(0.0014)\end{array}$ & $\begin{array}{c}-0.0101 * * * \\
(0.0031)\end{array}$ & $\begin{array}{c}-0.0141^{* *} \\
(0.0056)\end{array}$ & $\begin{array}{c}-0.0328^{* * *} \\
(0.0041)\end{array}$ & $\begin{array}{c}-0.0026^{* *} \\
(0.0012)\end{array}$ & $\begin{array}{c}-0.0130^{* * *} \\
(0.0048)\end{array}$ & $\begin{array}{c}-0.0121 \text { ** } \\
(0.0059)\end{array}$ & $\begin{array}{c}-0.0247^{* *} \\
(0.0121)\end{array}$ & $\begin{array}{c}-0.0487^{* *} \\
(0.0191)\end{array}$ & $\begin{array}{c}-0.0027^{* *} \\
(0.0012)\end{array}$ \\
\hline Head age & & $\begin{array}{c}0.4385 \text { ** } \\
(0.2110)\end{array}$ & & $\begin{array}{c}0.2488 \\
(0.1853)\end{array}$ & $\begin{array}{c}0.0195 \\
(0.0131)\end{array}$ & & $\begin{array}{l}0.5086^{*} \\
(0.2987)\end{array}$ & & $\begin{array}{c}0.4153 \\
(0.2963)\end{array}$ & $\begin{array}{l}0.0233^{*} \\
(0.0126)\end{array}$ \\
\hline Head age 2 & & $\begin{array}{c}-0.0039^{* *} \\
(0.0018)\end{array}$ & & $\begin{array}{l}-0.0023 \\
(0.0016)\end{array}$ & $\begin{array}{l}-0.0002 \\
(0.0001)\end{array}$ & & $\begin{array}{c}-0.0045^{*} \\
(0.0026)\end{array}$ & & $\begin{array}{l}-0.0038 \\
(0.0026)\end{array}$ & $\begin{array}{c}-0.0002 * \\
(0.0001)\end{array}$ \\
\hline Head edu & & $\begin{array}{c}-0.0722 \text { ** } \\
(0.0322)\end{array}$ & & $\begin{array}{c}-0.0491 * \\
(0.0293)\end{array}$ & $\begin{array}{c}-0.0039 * \\
(0.0021)\end{array}$ & & $\begin{array}{c}-0.0763 * \\
(0.0451)\end{array}$ & & $\begin{array}{l}-0.0714 \\
(0.0458)\end{array}$ & $\begin{array}{c}-0.0040 \text { * } \\
(0.0022)\end{array}$ \\
\hline Per size & & $\begin{array}{c}-0.9409 * \\
(0.5024)\end{array}$ & & $\begin{array}{c}-0.6195^{* *} \\
(0.2929)\end{array}$ & $\begin{array}{c}-0.0487^{* *} \\
(0.0245)\end{array}$ & & $\begin{array}{c}-0.9504^{* *} \\
(0.4614)\end{array}$ & & $\begin{array}{c}-0.8741^{* *} \\
(0.4135)\end{array}$ & $\begin{array}{c}-0.0490 * \\
(0.0265)\end{array}$ \\
\hline Elder Child & & $\begin{array}{c}0.2493 * * \\
(0.1147)\end{array}$ & & $\begin{array}{c}0.2315^{* *} \\
(0.0948)\end{array}$ & $\begin{array}{c}0.0182^{* *} \\
(0.0086)\end{array}$ & & $\begin{array}{l}0.2547^{*} \\
(0.1500)\end{array}$ & & $\begin{array}{c}0.3325^{* *} \\
(0.1630)\end{array}$ & $\begin{array}{c}0.0187^{* *} \\
(0.0086)\end{array}$ \\
\hline Elder agri & & $\begin{array}{l}-0.0905 \\
(0.3921)\end{array}$ & & $\begin{array}{c}0.2072 \\
(0.2931)\end{array}$ & $\begin{array}{c}0.0163 \\
(0.0248)\end{array}$ & & $\begin{array}{c}0.0038 \\
(0.4127)\end{array}$ & & $\begin{array}{c}0.3960 \\
(0.4847)\end{array}$ & $\begin{array}{c}0.0222 \\
(0.0249)\end{array}$ \\
\hline Fixed asset & & $\begin{array}{c}-0.0246^{*} \\
(0.0126)\end{array}$ & & $\begin{array}{l}-0.0141 \\
(0.0093)\end{array}$ & $\begin{array}{c}-0.0011 \text { * } \\
(0.0006)\end{array}$ & & $\begin{array}{c}-0.0200 * * * \\
(0.0076)\end{array}$ & & $\begin{array}{c}-0.0150 * \\
(0.0079)\end{array}$ & $\begin{array}{l}-0.0008 \\
(0.0006)\end{array}$ \\
\hline Agri asset & & $\begin{array}{c}0.4753^{* * *} \\
(0.1391)\end{array}$ & & $\begin{array}{c}0.2611^{* *} \\
(0.1132)\end{array}$ & $\begin{array}{c}0.0205^{* * *} \\
(0.0066)\end{array}$ & & $\begin{array}{c}0.4684^{* * *} \\
(0.1280)\end{array}$ & & $\begin{array}{c}0.3506^{* * * *} \\
(0.1243)\end{array}$ & $\begin{array}{c}0.0197^{* * * *} \\
(0.0075)\end{array}$ \\
\hline Irrigation & & $\begin{array}{c}0.7780^{* * *} \\
(0.2683)\end{array}$ & & $\begin{array}{c}0.4218^{* *} \\
(0.2117)\end{array}$ & $\begin{array}{c}0.0331^{* * *} \\
(0.0120)\end{array}$ & & $\begin{array}{c}0.7973^{* * *} \\
(0.2627)\end{array}$ & & $\begin{array}{c}0.6011^{* *} \\
(0.2495)\end{array}$ & $\begin{array}{c}0.0337^{* * *} \\
(0.0130)\end{array}$ \\
\hline Right & & $\begin{array}{c}-1.4091 * * * \\
(0.2017)\end{array}$ & & $\begin{array}{c}-0.9264^{* * *} \\
(0.2170)\end{array}$ & $\begin{array}{c}-0.0728^{* * *} \\
(0.0172)\end{array}$ & & $\begin{array}{c}-1.5786^{* * *} \\
(0.4892)\end{array}$ & & $\begin{array}{c}-1.4498^{* * *} \\
(0.4630)\end{array}$ & $\begin{array}{c}-0.0813^{* * *} \\
(0.0140)\end{array}$ \\
\hline Distance & & $\begin{array}{c}-0.0015^{* * *} \\
(0.0005)\end{array}$ & & $\begin{array}{c}-0.0011^{* * *} \\
(0.0004)\end{array}$ & $\begin{array}{c}-0.0001^{* * *} \\
(0.0000)\end{array}$ & & $\begin{array}{c}-0.0016^{* * *} \\
(0.0005)\end{array}$ & & $\begin{array}{c}-0.0015^{* * *} \\
(0.0005)\end{array}$ & $\begin{array}{c}-0.0001^{* * *} \\
(0.0000)\end{array}$ \\
\hline Location2 & & $\begin{array}{c}-0.3558^{*} \\
(0.2090)\end{array}$ & & $\begin{array}{l}-0.2616 \\
(0.1624)\end{array}$ & $\begin{array}{l}-0.0206 \\
(0.0126)\end{array}$ & & $\begin{array}{c}-0.4360 \text { * } \\
(0.2515)\end{array}$ & & $\begin{array}{c}-0.4402 * \\
(0.2492)\end{array}$ & $\begin{array}{c}-0.0247^{* *} \\
(0.0124)\end{array}$ \\
\hline Location3 & & $\begin{array}{c}-0.4074 \\
(0.2741)\end{array}$ & & $\begin{array}{l}-0.2372 \\
(0.2445)\end{array}$ & $\begin{array}{l}-0.0186 \\
(0.0175)\end{array}$ & & $\begin{array}{l}-0.4572 \\
(0.3175)\end{array}$ & & $\begin{array}{l}-0.3747 \\
(0.3575)\end{array}$ & $\begin{array}{l}-0.0210 \\
(0.0187)\end{array}$ \\
\hline constant & $\begin{array}{c}-1.7444^{* * *} \\
(0.1020)\end{array}$ & $\begin{array}{c}-11.0168 * \\
(6.2265)\end{array}$ & $\begin{array}{c}-1.3063^{* * *} \\
(0.3999)\end{array}$ & $\begin{array}{l}-5.0303 \\
(5.3869)\end{array}$ & & $\begin{array}{c}-3.1859 * * * \\
(0.9033)\end{array}$ & $\begin{array}{c}-12.8187 \\
(8.2971)\end{array}$ & $\begin{array}{c}-2.5491 * * \\
(1.1107)\end{array}$ & $\begin{array}{l}-8.7084 \\
(8.2222)\end{array}$ & \\
\hline Instrumental variables & No & No & Yes & Yes & Yes & No & No & Yes & Yes & Yes \\
\hline Wald $\chi^{2}$ & $25.4173^{* * *}$ & $133.7751^{* * *}$ & $6.3579 * *$ & $383.9628^{* * *}$ & $383.9628^{* * *}$ & & & $4.1382 * *$ & $35.3192 * * *$ & $35.3192 * * *$ \\
\hline Endogenous Wald $\chi^{2}$ & & & $1.3043^{* *}$ & $9.5047^{* * *}$ & $9.5047^{* * *}$ & & & 0.9126 ** & $4.8353^{* *}$ & $4.8353^{* *}$ \\
\hline $\mathrm{N}$ & 1652 & 1652 & 1652 & 1652 & 1652 & 1652 & 1652 & 1652 & 1652 & 1652 \\
\hline
\end{tabular}

Note: All numbers in parentheses are robust standard errors. Statistical significance at the $0.1,0.05$, and 0.01 level is denoted by ${ }^{* * *}$, and ${ }^{* * *}$, respectively. 
Table 3. Results of the econometric model of the impact of off-farm labor migration on land transfer-in with consideration of gender.

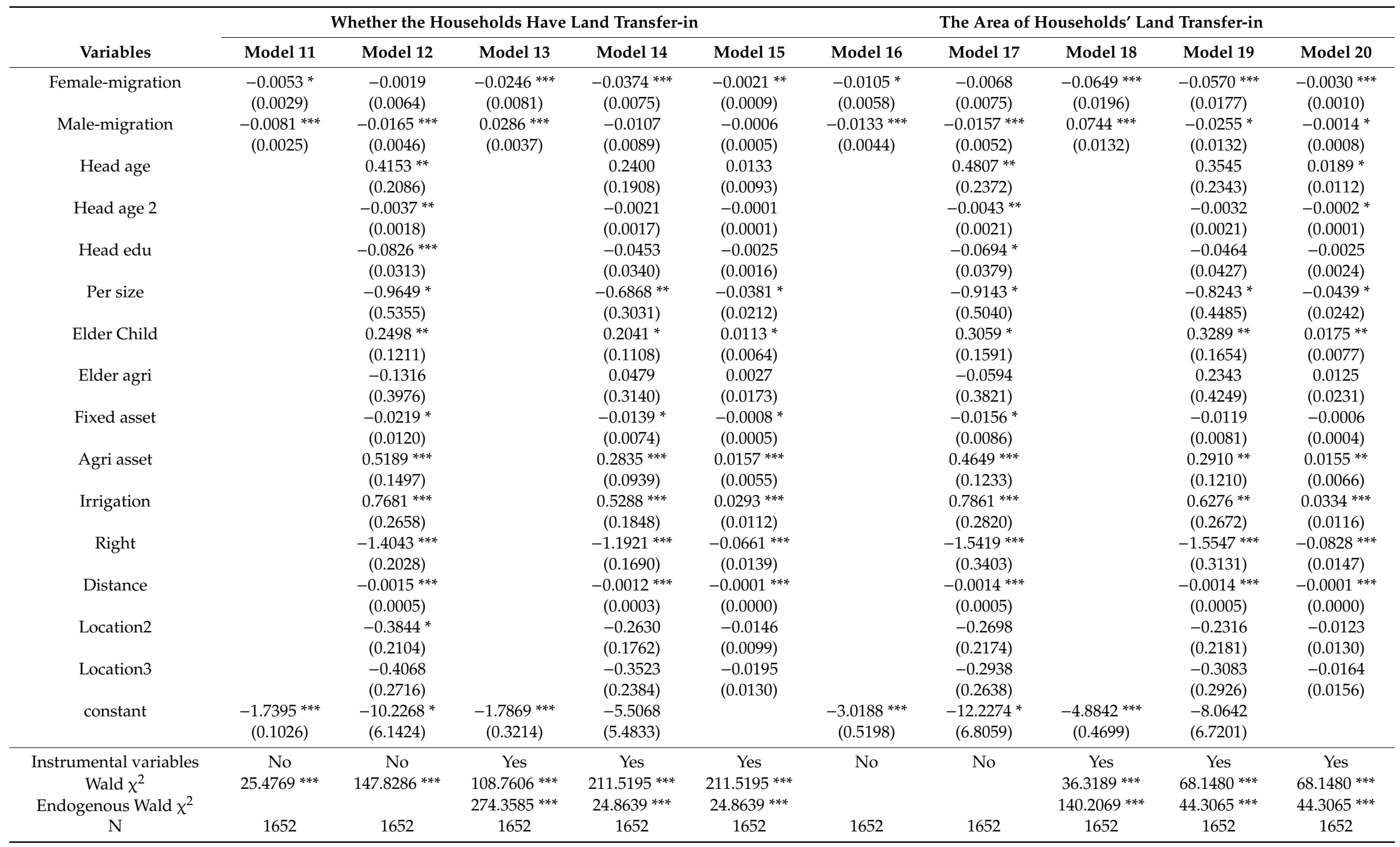

Note: All numbers in parentheses are robust standard errors. Statistical significance at the $0.1,0.05$, and 0.01 level is denoted by ${ }^{* * *}$, and ${ }^{* * *}$, respectively. 


\section{Discussion}

The present study focused on the impact of off-farm labor migration on rural households' land transfer-in behavior, especially the impact of female labor migration on land transfer-in behavior. Micro survey data of 1652 agricultural plots owned by 232 rural households in hilly areas of Sichuan Province were used under the guidance of NELM theory. IV-Probit and IV-Tobit models were used to analyze the impacts of off-farm labor migration on land transfer-in incidence and area. The contributions of this study are as follows: (1) In exploring the impact of off-farm labor migration on land transfer-in, this study focused on the impact of female off-farm labor migration on land transfer-in. The use of a gender perspective is novel. (2) In exploring the impact of off-farm labor migration on land transfer-in, this study not only examined land transfer-in incidence, but also land transfer-in area, which is more comprehensive and practical. (3) The use of IV-Probit and IV-Tobit models effectively dealt with the endogeneity problems existing in the models and made their results more accurate.

There are some similarities and differences between this study and previous ones. For example, consistent with $[19,29,31,39,67,68]$ and other studies, off-farm labor migration was negatively correlated with land transfer-in incidence and area. However, unlike the above studies, and especially unlike the conclusion of [31] — that female migration has no significant impact on rural households' land use-this study analyzed the impact of off-farm labor migration on land transfer from the perspective of gender and concluded that female migration inhibits land transfer-in more than male labor migration does. This may be because under the background of feminization and part-time employment of agriculture, women are the main participants in agricultural production activities and play an increasingly important role in family decision-making. This results in female migration having a greater inhibitory effect on land transfer-in decision-making than male migration. In addition, the core independent variable setting of this study is different from the studies by $[8,19,29,46]$. This study did not strictly distinguish between part-time and off-farm employment, but classified part-time and off-farm employment as off-farm labor migration. Unlike the studies by $[22,45]$ this study did not further explore whether there was a U-shaped relationship between off-farm migration and land transfer rates.

Based on the above discussion and conclusions, we can draw the following policy implications. First, the government should actively complete the confirmation and registration of land ownership as soon as possible, reduce or give up a large number of administrative orders to intervene in land adjustment, keep the first household contract responsibility system unchanged, promote land "separation of three rights" (right to use, right to ownership, and contract right), and stimulate the development of the land transfer market. Second, the government should accelerate the development of rural vocational education and rural professional households and, especially, increase vocational skills training for women remaining in agriculture, to improve the human resources endowment of the female labor force and expand the scale of agricultural production. The government should improve rural social public services and reduce the female' burden in housework and raising children so that the female labor force can have more energy to participate in rural market activities. Finally, the government should promote rural non-agricultural economic development to promote rural land transfer as well as to improve rural household income structures, increase the agricultural income proportion of household income, especially that of women, raise the economic status and decision-making power of women in the family, and keep the rural labor force in rural development.

This study discussed the impact of off-farm migration on land transfer-in by rural households from a gender perspective. This provides a new perspective by which to understand the land transfer-in behaviors of rural households in hilly areas. However, this study has some shortcomings. For example, the influence of off-farm labor migration on land transfer is a dynamic process. This study only analyzed this relationship using cross-sectional data; future studies could use panel data to gain better insights. Additionally, this study only focused on the impact of off-farm migration on land transfer-in, but land transfer has two dimensions: transfer-in and transfer-out. Future studies could also explore the impact of off-farm labor migration on land transfer-out. Moreover, this study adopts the data from 
the field survey in 2014, which is relatively weak in timeliness. Future studies can be analyzed with the latest data.

\section{Conclusions}

Based on the above analysis, this study drew the following three main conclusions:

1. There was a significant negative impact of off-farm labor migration on the land transfer-in incidence of rural households. Every $10 \%$ increase in off-farm labor migration reduced the probability of land transfer-in by $2.6 \%$ on average and the area of land transfer-in decreased by 2.7 mu on average.

2. From the perspective of gender, female migration had an obvious inhibitory effect on land transfer-in. Specifically, for every $10 \%$ increase in the female migration rate, the land transfer-in probability decreased by $2.1 \%$ on average and the area of land transfer-in decreased by $3 \mathrm{mu}$ on average. At the same time, there was no impact of male migration on rural household land transfer-in rates.

3. Other control variables, such as Head age, Head edu, Right, Per size, Agri asset, and Irrigation, all significantly impact on farmers' land transfer behavior and area.

Author Contributions: Data curation, K.H. and X.D.; Investigation, Y.L. and Z.Y.; Methodology, D.X.; Software, K.H. and Y.L.; Writing — original draft, K.H.; and Writing—review and editing, D.X. All authors have read and agreed to the published version of the manuscript.

Funding: This research was funded by National Natural Science Foundation of China (Grant Nos. 41801221, 41571527, 41601614, and 41701622); Innovation training program of Sichuan Agricultural University in 2019 (2019106226105); and Undergraduate research interest cultivation program in 2020 of Sichuan Agricultural University (Study on the relationship between livelihood transformation and sustainable land use of farmers in mountainous areas of Sichuan province).

Acknowledgments: We gratefully acknowledge financial supports from National Natural Science Foundation of China (Grant Nos. 41801221, 41571527, 41601614, and 41701622) and Innovation training program of Sichuan Agricultural University in 2019 (2019106226105). The authors also extend great gratitude to the anonymous reviewers and editors for their helpful review and critical comments.

Conflicts of Interest: The authors declare no conflict of interest.

\section{References}

1. De Brauw, A.; Huang, J.; Rozelle, S.; Zhang, L.; Zhang, Y. The Evolution of China's Rural Labor Markets during the Reforms. J. Comp. Econ. 2002, 30, 329-353. [CrossRef]

2. Cheng, M.; Liu, Y.; Zhou, Y. Measuring the symbiotic development of rural housing and industry: A case study of Fuping County in the Taihang Mountains in China. Land Use Policy 2019, 82, 307-316. [CrossRef]

3. Li, X.; Wang, X. Changes in agricultural land use in China: 1981-2000. Asian Geogr. 2003, 22, 27-42. [CrossRef]

4. Lin, J.Y. Rural reforms and agricultural growth in China. Am. Econ. Rev. 1992, 82, 34-51. [CrossRef]

5. Su, B.; Li, Y.; Li, L.; Wang, Y. How does nonfarm employment stability influence farmers' farmland transfer decisions? Implications for China's land use policy. Land Use Policy 2018, 74, 66-72. [CrossRef]

6. Unger, J.; Chan, A. Inheritors of the Boom: Private Enterprise and the Role of Local Government in a Rural South China Township. J. China 1999, 42, 45-74. [CrossRef]

7. Weitzman, M.L.; Xu, C. Chinese Township-Village Enterprises as Vaguely Defined Cooperatives. J. Comp. Econ. 1994, 18, 121-145. [CrossRef]

8. Xu, D.; Guo, S.; Xie, F.; Liu, S.; Cao, S. The impact of rural laborer migration and household structure on household land use arrangements in mountainous areas of Sichuan Province, China. Habitat Int. 2017, 70, 72-80. [CrossRef]

9. Brown, L.R. Who Will Feed China? Wake-Up Call for a Small Planet; Earthscan Publications: London, UK, 1995.

10. Chen, R.; Ye, C.; Cai, Y.; Xing, X.; Chen, Q. The impact of rural out-migration on land use transition in China: Past, present and trend. Land Use Policy 2014, 40, 101-110. [CrossRef]

11. Long, H. Land use policy in China: Introduction. Land Use Policy 2014, 40, 1-5. [CrossRef] 
12. Xu, D.; Zhang, J.; Rasul, G.; Liu, S.; Xie, F.; Cao, M.; Liu, E. Household livelihood Strategies and Dependence on Agriculture in the Mountainous Settlements in the Three Gorges Reservoir Area, China. Sustainability 2015, 7, 4850-4869. [CrossRef]

13. Deng, X.; Xu, D.; Zeng, M.; Qi, Y. Does early-life famine experience impact rural land transfer? Evidence from China. Land Use Policy 2019, 81, 58-67. [CrossRef]

14. Deng, X.; Xu, D.; Zeng, M.; Qi, Y. Does Internet use help reduce rural cropland abandonment? Evidence from China. Land Use Policy 2019, 89, 104243. [CrossRef]

15. Xu, D.; Deng, X.; Guo, S.; Liu, S. Labor migration and farmland abandonment in rural China: Empirical results and policy implications. J. Environ. Manag. 2019, 232, 738-750. [CrossRef] [PubMed]

16. Du, J.; Zeng, M.; Xie, Z.; Wang, S. Power of Agricultural Credit in Farmland Abandonment: Evidence from Rural China. Land 2019, 8, 184. [CrossRef]

17. Huang, Z.H.; Wang, P. Farmland transfer and its impacts on the development of modern agriculture: Status, problems and solutions. J. Zhejiang Univ. Sci. 2008, 2, 38-47. (In Chinese)

18. Benjamin, D.; Brandt, L. Property rights, labour markets, and efficiency in a transition economy: The case of rural China. Can. J. Econ. 2002, 35, 689-716. [CrossRef]

19. Kung, J.K. Off-Farm Labor Markets and the Emergence of Land Rental Markets in Rural China. J. Comp. Econ. 2002, 30, 395-414. [CrossRef]

20. Huang, J.; Gao, L.; Rozelle, S. The effect of off-farm employment on the decisions of households to rent out and rent in cultivated land in China. China Agric. Econ. Rev. 2012, 4, 5-17. [CrossRef]

21. Jin, S.; Deininger, K. Land rental markets in the process of rural structural transformation: Productivity and equity impacts from China. J. Comp. Econ. 2009, 37, 629-646. [CrossRef]

22. Xu, D.; Deng, X.; Huang, K.; Liu, Y.; Yong, Z.; Liu, S. Relationships between labor migration and cropland abandonment in rural China from the perspective of village types. Land Use Policy 2019, 88, 104164. [CrossRef]

23. Deng, X.; Xu, D.; Qi, Y.; Zeng, M. Labor Off-Farm Employment and Cropland Abandonment in Rural China: Spatial Distribution and Empirical Analysis. Int. J. Environ. Res. Public Health 2018, 15, 1808. [CrossRef] [PubMed]

24. Long, H.; Tu, S.; Ge, D.; Li, T.; Liu, Y. The allocation and management of critical resources in rural China under restructuring: Problems and prospects. J. Rural Stud. 2016, 47, 392-412. [CrossRef]

25. Xu, D.; Deng, X.; Guo, S.; Liu, S. Sensitivity of Livelihood Strategy to Livelihood Capital: An Empirical Investigation Using Nationally Representative Survey Data from Rural China. Soc. Indic. Res. 2018. [CrossRef]

26. Ministry of Agriculture and Rural Affairs of China (MARC). 2018. Available online: http://www.moa.gov.cn/ govpublic/NCJJTZ/201809/t20180914_6157385.htm (accessed on 6 October 2019). (In Chinese)

27. Deininger, K. Land Markets in Developing and Transition Economies: Impact of Liberalization and Implications for Future Reform. Am. J. Agric. Econ. 2003, 85, 1217-1222. [CrossRef]

28. Otsuka, K. Chapter 51 Efficiency and Equity Effects of Land Markets. AGRIC DEV 2007, 2671-2703. [CrossRef]

29. Che, Y. Off-farm employments and land rental behavior: Evidence from rural China. China Agric. Econ. Rev. 2016, 8, 37-54. [CrossRef]

30. Deininger, K.; Jin, S. The potential of land rental markets in the process of economic development: Evidence from China. J. Dev. Econ. 2005, 8, 241-270. [CrossRef]

31. Xie, Y.; Jiang, Q. Land arrangements for rural-urban migrant workers in China: Findings from Jiangsu Province. Land Use Policy 2016, 50, 262-267. [CrossRef]

32. Liu, S.; Xie, F.; Zhang, H.; Guo, S. Influences on rural migrant workers' selection of employment location in the mountainous and upland areas of Sichuan, China. J. Rural Stud. 2014, 33, 71-81. [CrossRef]

33. Zhu, N.; Luo, X. The impact of migration on rural poverty and inequality: A case study in China. Agric. Econ. 2010, 41, 191-204. [CrossRef]

34. Xu, D.-D.; Zhang, J.-F.; Xie, F.-T.; Liu, S.-Q.; Cao, M.-T.; Liu, E.-L. Influential factors in employment location selection based on "push-pull" migration theory: A case study in Three Gorges Reservoir area in China. J. Mt. Sci. 2015, 12, 1562-1581. [CrossRef]

35. Li, Y.; Liu, H.; Tang, Q.; Lu, D.; Xiao, N. Spatial-temporal patterns of China's interprovincial migration, 1985-2010. J. Geogr. Sci. 2014, 24, 907-923. [CrossRef]

36. Magnani, E.; Zhu, R. Gender wage differentials among rural-urban migrants in China. Reg. Sci. Urban Econ. 2012, 42, 779-793. [CrossRef] 
37. Zhang, K.H.; Song, S. Rural-urban migration and urbanization in China: Evidence from time-series and cross-section analyses. China Econ. Rev. 2003, 14, 386-400. [CrossRef]

38. Xu, D.; Peng, L.; Liu, S.; Su, C.; Wang, X.; Chen, T. Influences of migrant work income on the poverty vulnerability disaster threatened area: A case study of the Three Gorges Reservoir area, China. Int. J. Dis. Reduct. 2017, 22, 62-70. [CrossRef]

39. Wang, X.; Peng, L.; Xu, D.; Wang, X. Sensitivity of Rural Households' Livelihood Strategies to Livelihood Capital in Poor Mountainous Areas: An Empirical Analysis in the Upper Reaches of the Min River, China. Sustainability 2019, 11, 2193. [CrossRef]

40. Xu, D.; Ma, Z.; Deng, X.; Liu, Y.; Huang, K.; Zhou, W.; Yong, Z. Relationships between Land Management Scale and Livelihood Strategy Selection of Rural Households in China from the Perspective of Family Life Cycle. Land 2020, 9, 11. [CrossRef]

41. Yang, D.T. China's land arrangements and rural labor mobility. China Econ. Rev. 1997, 8, 101-115. [CrossRef]

42. Chen, F.; Zhai, W.J. Land transfer incentive and welfare effect research from perspective of farmers' behavior. Res. Econ. J. 2015, 10, 163-177. (In Chinese)

43. Long, H.; Liu, Y.; Li, X.; Chen, Y. Building new countryside in China: A geographical perspective. Land Use Policy 2010, 27, 457-470. [CrossRef]

44. Seto, K.C.; Reenberg, A.; Boone, C.G.; Fragkias, M.; Haase, D.; Langanke, T.; Marcotullio, P.; Munroe, D.K.; Olah, B.; Simon, D. Urban land teleconnections and sustainability. Proc. Natl. Acad. Sci. USA 2012, 109, 7687-7692. [CrossRef]

45. Deng, X.; Xu, D.; Zeng, M.; Qi, Y. Does labor off-farm employment inevitably lead to land rent out? Evidence from China. J. Mt. Sci. 2019, 16, 689-700. [CrossRef]

46. Xu, D.; Cao, S.; Wang, X.; Liu, S. Influences of labor migration on rural household land transfer: A case study of Sichuan Province, China. J. Mt. Sci. 2018, 15, 2055-2067. [CrossRef]

47. Yao, C.Y. Local versus global separability in agricultural household models: The factor price equalization effect of land transfer rights. Am. J. Agric. Econ. 2002, 84, 702-715. [CrossRef]

48. Chen, H.; Chen, Z.W. Analysis of non-synchronization about rural labor migration and land transfer: Data from China's rural fixed point in 1986-2010. Financ. Trade Res. 2013, 5, 32-38. (In Chinese)

49. Qian, Z.H. Does non-agricultural employment inevitably lead to the transfer of agricultural land-Based on the theoretical analysis of partial workers in the family and its interpretation of the concurrentization of Chinese farmers. Chin. Rural Econ. 2008, 10, 13-21. (In Chinese)

50. Ma, X.; Heerink, N.; van Ierland, E.; Shi, X. Land tenure insecurity and rural-urban migration in rural China. Pap. Reg. Sci. 2014, 95, 383-406. [CrossRef]

51. Li, X.C.; Yu, L.Q. Study on the correlation between rural surplus labor transfer and land transfer-Taking Liaoning Province as an example. Reform Strategy 2016, 11, 112-115. (In Chinese)

52. Cai, F. Family roles and gender characteristics in migration decisions. Popul. Res. 1997, 2, 7-12. (In Chinese)

53. Shang, C.R.; Wang, Z.H. Rural married women's non-agricultural employment and household land circulation. J. Nanjing Agric. Univ. Sci. 2014, 3, 62-70. (In Chinese)

54. Deng, X.; Zeng, M.; Xu, D.; Wei, F.; Qi, Y. Household Health and Cropland Abandonment in Rural China: Theoretical Mechanism and Empirical Evidence. Int. J. Environ. Res. Public Health 2019, 16, 3588. [CrossRef] [PubMed]

55. Yue, S.; Xu, D.; Liu, S. Research on Role Cognition and Employment Strategy of Rural Female Laborers in Sichuan, China. Sustainability 2019, 11, 1708. [CrossRef]

56. National Bureau of Statistics of China (NBSC). 2019. Available online: http://www.stats.gov.cn/tjsj/zxfb/ 201904/t20190429_1662268.html (accessed on 6 October 2019). (In Chinese)

57. Stark, O.; Bloom, D.E.; The New Economics of Labor Migration. The American Economic Review. 1985. Available online: https://www.jstor.org/stable/1805591 (accessed on 6 October 2019).

58. Peng, L.; Xu, D.; Wang, X. Vulnerability of rural household livelihood to climate variability and adaptive strategies in landslide-threatened western mountainous regions of the Three Gorges Reservoir Area, China. Clim. Dev. 2019, 11, 469-484. [CrossRef]

59. Chen, H.G.; Zhang, Y.Y. Impact of professional differentiation of rural women on their family's willingness to circulate contracted land: A comparative study on female's agricultural and non-agricultural employment. J. Nanjing Agric. Univ. Sci. 2014, 4, 57-65, 84. (In Chinese) 
60. Cao, S.; Xu, D.; Liu, Y.; Liu, S. The Impact of Rural Labor Migration on Elderly Health from the Perspective of Gender Structure: A Case Study in Western China. Sustainability 2019, 11, 5763. [CrossRef]

61. Guo, S.; Li, C.; Wei, Y.; Zhou, K.; Liu, S.; Xu, D.; Li, Q. Impact of land expropriation on farmers' livelihoods in the mountainous and hilly regions of Sichuan, China. J. Mt. Sci. 2019, 16, 2484-2501. [CrossRef]

62. Xue, K.; Xu, D.; Liu, S. Social Network Influences on Non-Agricultural Employment Quality for Part-Time Peasants: A Case Study of Sichuan Province, China. Sustainability 2019, 11, 4134. [CrossRef]

63. Cao, S.; Xu, D.; Liu, S. A Study of the Relationships between the Characteristics of the Village Population Structure and Rural Residential Solid Waste Collection Services: Evidence from China. Int. J. Environ. Res. Public Health 2018, 15, 2352. [CrossRef]

64. Luo, R.; Zhang, L.; Huang, J.; Rozelle, S. Elections, fiscal reform and public goods provision in rural China. J. Comp. Econ. 2007, 35, 583-611. [CrossRef]

65. Rozelle, S. Stagnation without Equity: Patterns of Growth and Inequality in China's Rural Economy. J. China 1996, 35, 63-92. [CrossRef]

66. Mullan, K.; Grosjean, P.; Kontoleon, A. Land Tenure Arrangements and Rural-Urban Migration in China. World Dev. 2011, 39, 123-133. [CrossRef]

67. Ji, X.; Qian, Z.; Zhang, L.; Zhang, T. Rural Labor Migration and Households' Land Rental Behavior: Evidence from China. China World Econ. 2018, 26, 66-85. [CrossRef]

68. Yan, X.; Huo, X. Drivers of household entry and intensity in land rental market in rural China. China Agric. Econ. Rev. 2016, 8, 345-364. [CrossRef]

(C) 2020 by the authors. Licensee MDPI, Basel, Switzerland. This article is an open access article distributed under the terms and conditions of the Creative Commons Attribution (CC BY) license (http://creativecommons.org/licenses/by/4.0/). 